\title{
PENGARUH TEKNIK RELAKSASI OTOT PROGRESIF TERHADAP KECEMASAN PADA PASIEN PRE OPERASI
}

\author{
Tori Rihiantoro*, Ririn Sri Handayani*, Niluh Made Wahyuningrat*, Suratminah** \\ *Jurusan Keperawatan Poltekkes Tanjungkarang \\ * Rumah Sakit dr. Hi. Abdul Moeloek Provinsi Lampung \\ E-mail: toririhiantoro@gmail.com
}

\begin{abstract}
Pada fase pre operasi, klien mengalami berbagai stresor yang dapat menyebabkan kecemasan. Kecemasan dapat memberikan efek yang dapat mempengaruhi fungsi fisiologis tubuh yang menyebabkan penundaan operasi dan terhambatnya penyembuhan penyakit pada klien. Penatalaksanaan kecemasan salah satunya dengan relaksasi otot progresif. Terapi ini akan merangsang pengeluaran zat kimia endorfin dan ekefalin serta merangsang signal otak yang menyebabkan otot rileks dan meningkatkan aliran darah ke otak. Penelitian ini bertujuan untuk mengetahui teknik relaksasi otot progresif terhadap penurunan kecemasan pada pasien pre operasi. Desain penelitian ini adalah pra-eksperimen dengan rancangan one group pretest and post test. Sampel penelitian berjumlah 30 orang dengan teknik purposive sampling. Hasil penelitan menunjukkan rata-rata skor kecemasan sebelum terapi relaksasi otot progresif adalah 54.17, dengan standar deviasi 5.427. Sedangkan untuk rata-rata skor kecemasan sesudah terapi relaksasi otot progresif adalah 50,33 dengan standar deviasi 4,999. Analisis uji non parametik menggunakan uji wilcoxon didapatkan hasil $\rho$ value 0.000 ( $\rho$ value $0.000<\alpha 0.05$ ), maka dapat disimpulkan bahwa ada pengaruh terapi relaksasi otot progresif terhadap tingkat kecemasan pada pasien pre operasi. Diharapkan agar terapi relaksasi otot progresif dapat dimasukkan kedalam program rumah sakit dalam menangani kecemasan pre operasi.
\end{abstract}

Kata kunci: Kecemasan, Pre Operasi, Relaksasi Otot Progresif

\section{LATAR BELAKANG}

Pembedahan merupakan pengalaman unik perubahan terancana pada tubuh terdiri dari tiga fase: praoperatif, intraoperatif, dan pascaoperatif (Kozier, 2011). Saat fase praoperasi klien megalami berbagai stresor yang dapat menyebabkan rasa takut dan ansietas pada klien. Berdasarkan data yang diperoleh dari World Health Organization (WHO) dalam Sartika (2013), tindakan operasi di Indonesia pada tahun 2012 mencapai 1,2 juta jiwa. Berdasarkan data tabulasi Nasional Departemen Kesehatan Republik Indonesia pada tahun 2009, tindakan pembedahan menempati ururan ke-11 dari 50 pertama penanganan pola penyakit di rumah sakit se Indonesia (Depkes RI, 2009). Berdasarkan hasil pre survei di ruang bedah salah satu rumah sakit di Kota Metro didapatkan data sebanyak 351 pasien menjalani pembedahan elektif dari bulan Juli - Desember tahun 2016.

Operasi atau tindakan medis pada umumnya menimbulkan rasa takut pada pasien. Apapun jenisnya baik operasi besar maupun operasi kecil merupaka suatu stressor yang dapat menimbulkan reaksi stress, kemudian diikuti dengan gejalagejala kecemasan, ansietas, atau depresi (Mansjoer, 2007). Kecemasan adalah perasaan takut yang tidak jelas dan tidak di dukung oleh situasi. Ketika merasa cemas, individu merasa tidak nyaman atau takut atau mungkin memiliki firasat akan ditimpa malapetaka padahal dia tidak mengerti mengapa emosi yang mengancam itu terjadi. Tidak ada objek yang dapat diidentifikasi sebagai stimulus ansietas (Comer,1992 dalam Videbeck, Sheila L., 2008). Faktor-faktor yang dapat menyebabkan kecemasan pasien pre operasi adalah takut terhadap nyeri, kematian, takut tentang ketidaktahuan penyakit, takut tentang deformitas dan ancaman lain terhadap citra tubuh (Muttaqin \& Sari, 2009).

Di Indonesia prevalensi kecemasan diperkirakan $9 \%-21 \%$ populasi umum, sedangkan angka populasi pasien preoperasi yang mengalami kecemasan 
sebesar $80 \%$. Menurut peneliti Simbolon (2015) menunjukan tingkat kecemasan dari 20 orang responden sebelum dilakukan intervensi pemberian terapi musik terdapat 13 orang $(65 \%)$ yang memiliki tingkat kecemasan berat dan 7 orang $(35 \%)$ yang memiliki tingkat kecemasan sedang. Penelitian Neno, Kristiyawati, \& Purnomo (2014) menunjukkan tingkat kecemasan dari 32 responden sebelum mendapatkan perlakuan yang mengalami kecemasan ringan 4 orang $(12,5 \%)$, kecemasan sedang sebanyak 17 orang $(53.1 \%)$, cemas berat sebanyak 10 orang $(33.1 \%)$, dan panik sebanyak 1 orang (3.1\%) Hasil penelitian lain yang mendukung adalah penelitian yang dilakukan Heriani Bahsoan (2013), didapatkan hasil dari 44 responden pra operasi, yang mengalami kecemasan ringan sebanyak 13 orang (29.5\%), kecemasan sedang sebanyak 13 orang (29.5\%), dan kecemasan berat sebanyak 18 orang $(40.9 \%)$.

Keadaan cemas pasien akan berpengaruh kepada fungsi tubuh menjelang operasi. Kecemasan yang tinggi, dapat mempengaruhi fungsi fisiologis tubuh yang ditandai dengan adanya peningkatan frekuensi nadi dan respirasi, pergeseran tekanan darah dan suhu, relaksasi otot polos pada kandung kemih dan usus, kulit dingin dan lembab, peningkatan respirasi, dilatasi pupil, dan mulut kering. Kondisi ini sangat membahayakan kondisi pasien, sehingga dapat dibatalkan atau ditundanya suatu operasi. Akibat lainnya, lama perawatan pasien akan semakin lama dan menimbulkan masalah finansial. Maka, perawat harus mampu mengatasi kecemasan pada pasien, sehingga kecemasan tersebut dapat dikurangi secara efektif (Smeltzer \& Bare, 2002 dalam Putri, Kristiyawati \& Arif, 2014).

Ada beberapa cara untuk menurunkan kecemasan pada pasien diantaranya; farmakologi, pendekatan suportif dan psikoterapi. Teknik utama psikoterapi dalam menangani kecemasan adalah dengan relaksasi dan bio feed back. Teknik relaksasi yang digunakan dalam kecemasan salah satunya berupa teknik relaksasi otot progresif (Smeltzer \& Bare, 2002 dalam Arbani, 2015).

Terapi relaksasi otot progresif yaitu terapi dengan cara peregangan otot kemudian dilakukan relaksasi otot (Gemilang, 2013 dalam Rahayu, 2014). Relaksasi progresif dilakukan dengan cara klien menegangkan dan melemaskan sekelompok otot secara berurutan dan memfokuskan perhatian pada perbedaan perasaan yang dialami antara saat kelompok relaks dan saat otot tersebut tegang (Kozier, 2011). Penelitian Jacobson (1938) dalam Soewondo (2012) mengemukakan bahwa relaksasi otot progresif sebagai suatu program untuk melatih orang merileks otot-otot secara keseluruhan. Ketegangan menyebabkan serabut - serabut otot kontraksi, mengecil dan menciut. Ketegangan timbul bila seseorang cemas dan stres ini bisa hilang dengan menghilangkan ketegangan.

Dalam penelitian ini relaksasi progresif dapat digunakan untuk mengurangi kecemasan, karena dapat menekan saraf simpatis di mana dapat menekan rasa tegang yang dialami oleh individu secara timbal balik, sehingga timbul counter conditioning (penghilangan). Relaksasi diciptakan setelah mempelajari sistem kerja saraf manusia, yang terdiri dari sistem saraf pusat dan sistem saraf otonom. Sistem saraf otonom ini terdiri dari dua subsistem yaitu sistem saraf simpatis dan sistem saraf parasimpatis yang kerjanya saling berlawanan. Sistem saraf simpatis lebih banyak aktif ketika tubuh membutuhkan energi. Misalnya pada saat terkejut, takut, cemas atau berada dalam keadaan tegang. Pada kondisi seperti ini, sistem saraf akan memacu aliran darah ke otot-otot skeletal, meningkatkan detak jantung, kadar gula dan ketegangan menyebabkan serabutserabut otot kontraksi, mengecil dan menciut. Sebaliknya, relaksasi otot berjalan bersamaan dengan respon otonom dari saraf parasimpatis. Sistem saraf parasimpatis mengontrol aktivitas yang berlangsung selama penenangan tubuh, misalnya penurunan denyut jantung setelah fase ketegangan dan menaikkan aliran 
darah ke sistem gastrointestinal (Ramadani \& Putra, 2009). Sehingga kecemasan akan berkurang dengan dilakukannya relaksasi progresif.

Dari beberapa penelitian didapat bahwa penatalakasaan nonfarmakologis dapat menurunkan kecemasan diantaranya: terapi musik dapat menurunkan kecemasan (Ferawati, 2015), terapi ralaksasi napas dalam dapat menurunkan tingkat kecemasan (Istikomah \& Murwati, 2016), terapi imajinasi terbimbing dapat menurunkan tingkat kecemasan (Sarsito, 2015) dan terapi relaksasi otot progresif dapat menurunkan tingkat kecemasan (Deliyani, Majudin \& Adiningsih, 2015).

Menurut peneliti Rahayu (2014) menunjukkan bahwa dari responden yaitu 40 klien sebelum dilakukan terapi otot progresif jumlah klien yang mengalami kecemasan berat adalah 25 orang $(62,5 \%)$, dan tidak ada yang tidak menderita kecemasan. Sesudah dilakukan terapi otot progresif jumlah klien yang mengalami kecemasan sedang adalah 12 orang (30\%), dan jumlah klien yang mengalami kecemasan berat adalah 6 orang $(15 \%)$. Sementara Triwijaya (2014) menunjukkan tingkat kecemasan sebagian besar responden sebelum mendapatkan perlakuan yang mengalami cemas ringan sebanyak 4 orang $(8.7 \%)$, cemas sedang sebanyak 40 orang $(87.0 \%)$, cemas berat sebanyak 2 orang (4.3\%). Sedangkan sesudah perlakuan yang mengalami cemas ringan sebanyak 34 orang (73.9\%), cemas sedang sebanyak 12 orang $(26.1 \%)$, dan yang mengalami cemas berat tidak ada.

\section{METODE}

Jenis penelitian yang digunakan dalam penelitian ini adalah jenis penelitian kuantitatif, menggunakan rancangan penelitian pra-eksperimen dengan One grup pretest-postest design. Pada penelitian ini peneliti ingin mendapatkan nilai kecemasan sebelum dan sesudah dilakukan intervensi latihan relaksasi otot progresif.
Populasi yang digunakan dalam penelitian ini adalah 58 pasien yang menjalani pembedahan elektif di ruang bedah, dengan jumlah sampel sebanyak 30 responden. Teknik sampling yang digunakan adalah purposive sampling.

Instrumen yang digunakan berupa berupa lembar kuesioner berdasarkan Zung Self-Rating Anxiety Scale (SAS/SRAS) adalah penilaian kecemasan pada pasien yang dirancang oleh William W.K.Zung, dikembangkan berdasarkan gejala kecemasan dalam diagnostic and Statistical Manual of Mental Disorders (DSM-II) dan dimodifikasi dengan menyesuaikan situasi pre operasi. Teknik pengumpulan data pada penelitian ini yaitu peneliti melakukan penilaian kecemasan dengan menggunakan angket berupa lembar kuisoner Zung Self-Rating Anxiety Scale (ZSRAS) pada pasien pre operasi elektif 24 jam sebelum operasi, kemudian peneliti memberikan intervensi teknik relaksasi otot progresif setelah itu peneliti mengkaji ulang kecemasan responden dengan lembar kuisoner Zung Self-Rating Anxiety Scale (SAS/SRAS).

\section{HASIL}

\section{Karakteristik Responden kelamin}

Responden dalam penelitian ini berjumlah 30 orang dengan karakteristik jenis kelamin terbanyak perempuan $(56,7 \%)$, berusia dewasa diantara usia 18 sampai dengan 65 tahun dengan rata-rata 49,03 tahun. Berdasarkan tingkat pendidikan sebagian besar responden berpendidikan dasar $(56,7 \%)$.

\section{Analisis Univariat}

Tabel 1: Distribusi kecemasan sebelum dan sesudah dilakukan terapi relaksasi otot progresif

\begin{tabular}{lcccccc}
\hline Kecemasan & Mean & Median & SD & Min & Max & $n$ \\
\hline Sebelum & 54.17 & 53.50 & 5.427 & 46 & 65 & \multirow{3}{*}{30} \\
\hline Sesudah & 50.33 & 48.50 & 4,999 & 43 & 59 & \\
\hline
\end{tabular}


Berdasarkan tabel di atas diketahui bahwa rata-rata skor kecemasan sebelum diberikan terapi relaksasi otot progresif adalah 54,17 dengan standar deviasi 5,427, dan skor kecemasan terendah adalah 46 serta skor kecemasan tertinggi adalah 65 . Sedangkan setelah terapi relaksasi otot progresif rata-rata skor kecemasan sebesar 50,33 dengan standar deviasi 4,999, dan skor kecemasan terendah adalah 43 serta skor kecemasan tertinggi adalah 59.

\section{Uji Normalitas}

Tabel 2: Uji normalitas data nilai kecemasan sebelum dan setelah dilakukan terapi relaksasi otot progresif

\begin{tabular}{lc}
\hline Kecemasan & Kolmogorov-Smirnov \\
\cline { 2 - 2 } & $p$-value \\
\hline Sebelum & 0,335 \\
\hline Setelah & 0,026 \\
\hline
\end{tabular}

Berdasarkan tabel di atas menunjukkan bahwa nilai nilai $\mathrm{p}$ sebelum relaksasi otot progresif sebesar 0,335 dan sesudah relaksasi otot progresif sebesar 0,026. Salah satu nilai kurang dari 0,05 sehingga disimpulkan bahwa data tidak memenuhi asumsi distribusi normal. Selanjutnya uji statistik ditentukan dengan Wilcoxon Signed Ranks.

\section{Analisis Bivariat}

Tabel 3: Distribusi hasil analisis uji Wilcoxon Signed Ranks Test

\begin{tabular}{lcc}
\hline Kecemasan & $\begin{array}{c}\text { Median } \\
(\text { Min }- \text { Max })\end{array}$ & Nilai p \\
\cline { 1 - 2 } Sebelum & $48(46-52)$ & \multirow{2}{*}{0,000} \\
\hline Setelah & $46(44-49)$ & \\
\hline
\end{tabular}

Berdasarkan tabel di atas diperoleh hasil $p$-value sebesar $(0,000)<\alpha(0,05)$ sehingga dapat disimpulkan bahwa terdapat perbedaan yang antara skor kecemasan sebelum terapi relaksasi otot progresif dan skor kecemasan sesudah terapi relaksasi otot progresif. Ini menunjukan bahwa terdapat pengaruh terapi relaksasi otot progresif terhadap kecemasan pasien pre operasi.

\section{PEMBAHASAN}

\section{Kecemasan sebelum dan sesudah terapi}

Berdasarkan hasil dapat dilihat bahwa rata-rata skor kecemasan pada pasien pre operasi dapat dikategorikan sedang dan berat. Menurut Smeltzer \& Bare (2001) dalam Putri, Kristiyawati \& Arif (2014), kecemasan yang tinggi, dapat mempengaruhi fungsi fisiologis tubuh yang ditandai dengan adanya peningkatan frekuensi nadi dan respirasi, pergeseran tekanan darah dan suhu, relaksasi otot polos pada kandung kemih dan usus, kulit dingin dan lembab, peningkatan respirasi, dilatasi pupil, dan mulut kering. Kondisi ini sangat membahayakan kondisi pasien, sehingga dapat dibatalkan atau ditundanya suatu operasi. Akibat lainnya, lama perawatan pasien akan semakin lama dan menimbulkan masalah finansial maka diperlukan penatalaksanaan kecemasan pada pasien tersebut. Sehingga dilakukan terapi relaksasi otot progresif dan dilakukan pengukuran.

Berdasarkan hasil penelitian juga dapat dilihat bahwa terjadi penurunan ratarata skor kecemasan pada pasien pre operasi setelah diberikan terapi relaksasi otot progresif dalam kategori ringan sampai sedang.

Terapi relaksasi progresif dapat digunakan untuk mengurangi kecemasan, karena dapat menekan saraf simpatis di mana dapat menekan rasa tegang yang dialami oleh individu secara timbal balik, sehingga timbul counter conditioning (penghilangan). Relaksasi diciptakan setelah mempelajari sistem kerja saraf manusia, yang terdiri dari sistem saraf pusat dan sistem saraf otonom. Sistem saraf otonom ini terdiri dari dua subsistem yaitu sistem saraf simpatis dan sistem saraf parasimpatis yang kerjanya saling berlawanan. Sistem saraf simpatis lebih 
banyak aktif ketika tubuh membutuhkan energi. Misalnya pada saat terkejut, takut, cemas atau berada dalam keadaan tegang. Pada kondisi seperti ini, sistem saraf akan memacu aliran darah ke otot-otot skeletal, meningkatkan detak jantung, kadar gula dan ketegangan menyebabkan serabutserabut otot kontraksi, mengecil dan menciut. Sebaliknya, relaksasi otot berjalan bersamaan dengan respon otonom dari saraf parasimpatis. Sistem saraf parasimpatis mengontrol aktivitas yang berlangsung selama penenangan tubuh, misalnya penurunan denyut jantung setelah fase ketegangan dan menaikkan aliran darah ke sistem gastrointestinal (Ramadani \& Putra, 2009). Sehingga kecemasan akan berkurang dengan dilakukannya relaksasi progresif.

Berdasarkan penelitian, setelah dilakukan terapi relaksasi otot progresif terjadi perubahan pada skor kecemasan. Hal itu disebabkan karena tubuh menjadi rileks. Dengan demikian ketika dilakukan pengukuran skor kecemasan akan mengalami penurunan dibandingkan dengan sebelum diberikan terapi relaksasi otot progresif.

\section{Pengaruh terapi relaksasi otot progresif terhadap kecemasan pasien pre operasi}

Hasil penelitian menyimulkan bahwa ada perbedaan sebelum dan sesudah terapi relaksasi otot progresif. Hal ini berarti terapi relaksasi otot progresif berpengaruh dalam menurunkan kecemasan pasien pre operasi.

Pasien pre operasi dapat mengalami kecemasan, hal ini merupakan respon psikologis yang wajar. Kecemasan yang dialami dapat berada pada rentan respon ringan, sedang, berat dan panik. Tindakan untuk mengurangi kecemasan salah satunya menggunakan teknik relaksasi progresif. Terapi relaksasi progresif bertujuan untuk menghilangkan ketegangan sehingga menurunkan perasaan cemas. Efektivitas latihan relaksasi progresif adalah salah satu bentuk self control coping skill. Jacobson (1938) dalam Soewondo (2012) mengemukakan bahwa metode relaksasi progresif untuk melawan rasa cemas, stres dan tegang. Hasil penelitiannya menunjukkan bahwa apabila seseorang mengalami ketegangan dapat menyebabkan serabut-serabut otot kontraksi, mengecil dan menciut. Ketegangan timbul bila seseorang cemas dan stres bisa hilang dengan menghilangkan ketegangan.

Hasil penelitian ini sejalan dengan dengan penelitian sebelumnya yaitu penelitian Uskenat (2012) menunjukkan bahwa ada perbedaan tingkat kecemasan pada pasien pre operasi dengan general anestesi sebelum dan sesudah diberikan relaksai otot progresif, penelitian ini menunjukkan hasil yang sangat signifikan dengan $\mathrm{p}=0,000$ atau $<0,05$ sehingga terapi relaksasi progresif terbukti dapat mengurangi tingkat kecemasan.

Tindakan operasi atau pembedahan merupakan pengalaman yang bisa menimbukan kecemasan, oleh karena itu berbagai kemungkinan buruk bisa terjadi yang akan membahayakan pasien. Kecemasan berhubungan dengan segala macam prosedur asing yang harus dijalani pasien dan juga ancaman terhadap keselamatan jiwa akibat prosedur pembedahan dan tindakan pembiusan. Keperawatan pre operatif merupakan tahapan awal dari keperawatan perioperatif. Sehingga pasien pada saat akan menjalani operai perlu adanya penanganan akan kecemasan pasien, dengan pemberian terapi relaksasi otot progresif dapat membantu klien untuk rileks serta dapat menurunkan kecemasan klien, sehingga dapat berdampak baik akan kelancaran jalannya operasi.

Berdasarkan hasil uji Wilcoxon Signed Ranks, disimpulkan bahwa terdapat perbedaan kecemasan sebelum dan sesudah terapi relaksasi otot progresif. Terjadi perbedaan antara kecemasan sebelum diberikan terapi relaksasi otot progresif dan sesudah terapi relaksasi otot progresif dapat disebabkan oleh beberapa faktor yang berpengaruh, diantaranya usia, jenis kelamin dan jenjang pendidikan.

Bila dipandang berdasarkan usia maka responden yang paling banyak 
adalah usia lansia awal (40,0\%) yang mana semakin bertambahnya usia seseorang dapat menjadikannya lebih sentitif, mudah tersinggung dan juga dalam menerima informasi terbaru tentang cara menangani kecemasan akan kesulitan dikarenakan usia lansia sudah mengalami berbagai penurunan fisik dan memori, sehingga dalam memberikan terapi akan mengalami kesulitan. Hal ini mungkin jika dilihat berdasarkan jenis kelamin jumlah responden perempuan lebih banyak dibandingkan dengan jumlah laki-laki yaitu $56,7 \%$, sehingga perempuan lebih menggunakan emosinya dibandingkan akal, sehingga ketika akan menjalani operasi maka perempuan cenderung lebih cemas yang akan berdampak pada perubahan baik fisiologis, kognitif dan perilakunya, yang dapat berdampak buruk pada kelancaran operasi. Berdasarkan hasil penelitian jika dilihat berdasarkan tingkat pendidikan responden yang paling banyak adalah pendidikan dasar sebanyak 17 responden $(56,7 \%)$. responden yang tingkat pendidikan rendah akan mempengaruhi pengetahuan responden tentang bagaimana cara menangani kecemasan yang dialami sehingga responden lebih cemas dibandingkan dengan yang lain.

\section{KESIMPULAN}

Berdasarkan hasil penelitian dapat disimpulkan bahwa telah terjadi penurunan nilai kecemasan dari niilai rata-rata sebelum terapi sebesar 54,17 menjadi 50,33 setelah diberikan terapi relaksasi otot progresif. Hasil analisis lebih lanjut menunjukan bahwa terdapat perb perbedaan antara skor kecemasan sebelum dan sesudah terapi relaksasi otot progresif (nilai $\rho=0.000$ ). Dengan demikian disimpulkan bahwa terapi relaksasi otot progresif berpengaruh untuk menurunkan kecemasan pada pasien pre operasi.

Berdasarkan kesimpulan tersebut maka diharapkan agar terapi relaksasi otot progresif dapat dimasukkan kedalam salah dalam menangani katu alternatif rencana dan tindakan keperawatan untuk mengatasi kecemasan pasien pre operasi di rumah sakit. Selanjutnya rumah sakit dapat menerbitkan SOP tentang teknik relaksasi terutama terapi terapi relaksasi otot progresif sebagai pedoman untuk dilakukannya tindakan tersebut.

\section{DAFTAR PUSTAKA}

Arbani, F. A. (2015). Hubungan Komunikasi Terapeutik Dengan Tingkat Kecemasan Pasien Pre Operasi di Rs Pku Muhamadiyah Sukoharjo.

http://www.stikeskusumahusada.ac.i d/digilib/download.php?id=1207 Diperoleh tanggal 3 Januari 2017.

Kozier, Erb, Berman, Snyder. (2010). Buku Ajar Fundamental Keperawatan : Konsep, Proses, \& Praktik (Edisi 7, volume 2). Jakarta: EGC.

Neno, M. L., Kristiyawati, S. P., \& Purnomo, E. C. (2013). Pengaruh Terapi Relaksasi Masase Punggung Terhadap Penurunan Tingkat Kecemasan Pada Pasien Pre Operasi Bedah Mayor http://pmb.stikestelogorejo.ac.id/ejou rnal/index.php/ilmukeperawatan/artic le/download/180/204 Diperoleh tanggal 27 Desember 2016.

Rahayu, (2014). pengaruh terapi relaksasi otot progresif terhadap penurunan tingkat kecemasan pada klien diabetes mellitus tipe 2 di Wilayah Kerja Puskesmas Karangdoro Semarang http://pmb.stikestelogorejo.ac.id/ejou rnal/index.php/ilmukeperawatan/artic le/download/264/289 Diperoleh tanggal 27 Desember 2016.

Smeltzer \& Bare. (2002). Buku Ajar Keperawata Medikal-Bedah. Jakarta: EGC.

Safitri. (2015). Aplikasi Pemberian Informasi Pra Operasi Terhadap Tingkat Kecemasan Pada Asuhan Keperawatan Tn. K Dengan Pra Bedah Hernia Inguinalis Dekstra di 
Ruang Bedah Kantil I RSUD Karanganyar

(KTI)http://stikeskusumahusada.ac.i d/digilib/download.php?id=1428

Diperoleh tanggal 26 Desember 2016.

Simbolon, (2015). Pengaruh Terapi Musik Terhadap Tingkat Kecemasan Pada Pasien Pre Operasi Di Ruang Rawat Bedah Rumah Sakit Santa Elisabeth Medan http://jurnal.stikeselisabethmedan.ac. id/index.php/elisabeth/issue/downloa d/22/5 Diperoleh tanggal 26 Desember 2016.

Triwijaya, (2014). Pengaruh Teknik Relaksasi Otot Progresif Terhadap Penurunan Tingkat Kecemasan Ibu Intrantal Kala I http://download.portalgaruda.org/arti cle.php?article Diperoleh tanggal 26 Desember 2016.

Videbeck, S. L. (2008). Buku Ajar Keperawatan Jiwa. Jakarta: Buku Kedokteran EGC. 